\title{
Effect of poplar trees on nitrogen and water balance in outdoor pig production - A case study in Denmark
}

\author{
Kiril Manevski $^{\text {a,* }}$, Malene Jakobsen ${ }^{a}$, Anne Grete Kongsted ${ }^{a}$, Petros Georgiadis ${ }^{b}$, Rodrigo Labouriau ${ }^{\text {c }}$, \\ John Erik Hermansen ${ }^{a}$, Uffe Jørgensen ${ }^{a}$ \\ a Department of Agroecology, Aarhus University, Blichers Allé 20, 8830 Tjele, Denmark \\ b Department of Geosciences and Natural Resource Management, Copenhagen University, Rolighedsvej 23, 1958 Copenhagen, Denmark \\ c Department of Mathematics, Aarhus University, Ny Munkegade 118, 8000 Aarhus, Denmark
}

\section{H I G H L I G H T S}

- A combined production of poplars and pigs was hypothesised to lower nitrate leaching.

- Mean annual nitrate leaching ranged from 32 up to $289 \mathrm{~kg} \mathrm{~N} \mathrm{ha}^{-1}$ depending on treatment.

- Poplar zone showed 75-80\% lower nitrate leaching compared to grass-clover zone.

- Additional measures are needed to reduce nitrate losses on a mean area basis.

- CoupModel and Daisy were found useful for water balance analyses of agroforestry systems.

\section{A R T I C L E I N F O}

\section{Article history:}

Received 14 April 2018

Received in revised form 26 July 2018

Accepted 26 July 2018

Available online 27 July 2018

Editor: Ouyang Wei

\section{Keywords:}

Drainage

Evapotranspiration

Grass-clover

Lactating sows

Organic

Poplar

Simulation modelling

Soil nitrate
G R A P H I C A L A B S T R A C T

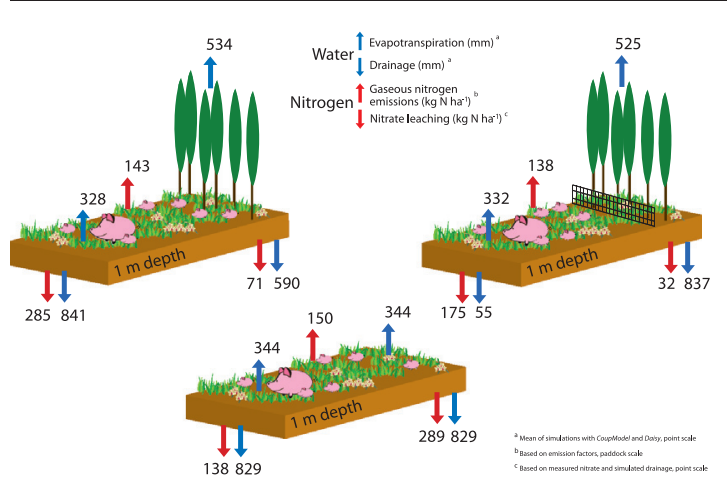

\begin{abstract}
A B S T R A C T
Nitrate leaching from outdoor pig production is a long-standing environmental problem for surface and groundwater pollution. In this study, the effects of inclusion of poplar trees in paddocks for lactating sows on nitrogen $(\mathrm{N})$ balances were studied for an organic pig farm in Denmark. Vegetation conditions, soil water and nitrate dynamics were measured in poplar and grass zones of paddocks belonging to main treatments: access to trees (AT), no access to trees (NAT) and a control without trees (NT), during the hydrological year April 2015 to April 2016. Soil water drainage for each zone, simulated by two simulation models (CoupModel and Daisy), was used to estimate nitrate leaching from the zones in each paddock. $\mathrm{N}$ balances (input minus output) for the treatments were computed and compared.

The results showed that, in terms of annual water balance and regardless of treatment, simulated evapotranspiration of poplar was 560-569 and 489-498 $\mathrm{mm}$ for CoupModel and Daisy, respectively, and corresponding evapotranspiration of grass-clover was 250 and $400 \mathrm{~mm}$, against precipitation of $1076 \mathrm{~mm}$. Simulated drainage below the root zone varied as 620-723 $\mathrm{mm}$ for Daisy and 568-958 $\mathrm{mm}$ for CoupModel, the higher end of the latter being probably overestimated. Annual nitrate leaching ranged from $32 \mathrm{~kg} \mathrm{~N} \mathrm{ha}^{-1}$ in the poplar zone of NAT up to $289 \mathrm{~kg} \mathrm{~N} \mathrm{ha}^{-1}$ in the control grass zone of NT. The poplar zone showed significantly lower nitrate leaching, by $75-80 \%$, compared to the grass zone. For the control NT treatment, nitrate leaching was approximately $50 \%$ higher in the grass zone closest to the hut compared to the grass zone further away. NT treatment also had the largest surface $\mathrm{N}$ balance of $468 \mathrm{~kg} \mathrm{~N}^{-1}$ compared to 436 and $397 \mathrm{~kg} \mathrm{~N} \mathrm{ha}^{-1}$ for AT and NAT, respectively. When $\mathrm{N}$ losses by leaching and volatilisation were included, soil $\mathrm{N}$ balances were 118,157 and $113 \mathrm{~kg} \mathrm{~N} \mathrm{ha}^{-1}$
\end{abstract}

\footnotetext{
* Corresponding author.

E-mail addresses: kiril.manevski@agro.au.dk (K. Manevski), malene.jakobsen@agro.au.dk (M. Jakobsen), anneg.kongsted@agro.au.dk (A.G. Kongsted), petrosgeor@ign.ku.dk (P. Georgiadis), rodrigo.labouriau@math.au.dk (R. Labouriau), john.hermansen@agro.au.dk (J.E. Hermansen), uffe.jorgensen@agro.au.dk (U.Jørgensen).
} 
for AT, NAT and NT, respectively. Overall, the two simulation models were found useful tools for analyses of water balance for complex agroforestry systems. The findings collectively suggest that it is possible to decrease nitrate leaching from outdoor pig production on sandy soils by inclusion of poplar trees. Additional measures are nevertheless needed to reduce $\mathrm{N}$ losses on a mean area basis in paddocks with $20 \%$ tree cover.

(C) 2018 Elsevier B.V. All rights reserved.

\section{Introduction}

Compared to conventional indoor pig farming, outdoor pig farming meets the behavioral requirements of the pigs (Thorslund et al., 2017), whereas lower stocking density and access to organic roughage are suggested to contribute to the low use of antibiotics in organic production (Bonde and Sørensen, 2004). However, livestock farming is a potential source of reactive nutrients, especially of nitrogen $(\mathrm{N})$, to the environment, and outdoor organic pig farming is no exception. The manure excreted by the pigs is unevenly distributed in the paddocks, creating accumulation of $\mathrm{N}$ in relatively small areas, so called 'hotspots' (Eriksen et al., 2006a). These hotspots contain substantial amounts of $\mathrm{N}$ and a wide range of 137 to $626 \mathrm{~kg} \mathrm{~N} \mathrm{ha}^{-1}$ have been reported, depending on stocking density, animal group and vegetation cover (Eriksen and Kristensen, 2001; Eriksen et al., 2002; Eriksen et al., 2006b; Jørgensen et al., 2018; Williams et al., 2000; Worthington and Danks, 1992). The surplus of $\mathrm{N}$ in the soil can potentially be leached, volatilised/denitrified, taken up by plants or built into the soil organic pool, and the prevalence of these pathways largely depends on the local pedo-climatic conditions. For sandy soils under temperate climate with high winter rainfall, nitrate leaching is of concern as it is the largest contributor of $\mathrm{N}$ found in the surface- and groundwater (Halberg et al., 2010; Hashemi et al., 2016).

Reducing the stocking density and adjusting the level of dietary nutrients have been reported to decrease nitrate leaching in outdoor pig farms (Stauffer et al., 1999; Webb et al., 2014), though production and competitiveness on the market may also be compromised. Another relevant factor for decreasing nitrate leaching is vegetation cover. Williams et al. (2005) reported about 50\% lower leaching from paddocks with grass ( $\left.137 \mathrm{~kg} \mathrm{~N} \mathrm{ha}^{-1}\right)$ compared to stubble $\left(235 \mathrm{~kg} \mathrm{~N} \mathrm{ha}^{-1}\right)$ on outdoor pig farms in the UK. Grasses are efficient in N uptake due to their fast regrowth after grazing and already developed root system. However, there is a risk of grass cover destruction due to pigs' treading and rooting behaviour (Eriksen et al., 2006b). Partly destroyed grass takes up less $\mathrm{N}$ during the main growing season and may exacerbate the situation the following year due to mineralisation of residues in spring (e.g., Pugesgaard et al., 2017). Regular moving of the huts and the feeding place in the range area where the pigs reside and excrete may lead to a more uniform nitrogen distribution and thereby decrease pressure on the grass cover (Eriksen et al., 2002). However, this does not always result in decreased nitrate leaching, as found in Quintern and Sundrum (2006). Moreover, soil mineral N, hence the risk for nitrate leaching, has been reported as independent of grass cover (Eriksen et al., 2006b), prompting for additional strategies to be investigated.

Silvopastoral agroforestry, i.e. combination of trees and grasses in the same field for grazing animals, might be a viable option because the excretory behaviour of the pigs is influenced by type and position of the various resources in the paddock (Eriksen et al., 2002; Quintern and Sundrum, 2006). Horsted et al. (2012) found that growing pigs performed $50 \%$ of all excretory behaviour in a zone with willow (Salix spp.), despite this zone accounting for only $15 \%$ of the available outdoor area in the paddocks. Trees such as willow and poplar (Populus spp.) can relatively easy be incorporated into silvopastoral agroforestry systems for several reasons. Firstly, they are fast growing perennial plants and, depending on the desired end product and the local climatic conditions, they can be managed/coppiced for rotation periods of $2-6,10-15$ or 25-40 year. Secondly, their root system is deep and extensive, has moderate soil water requirement and free draining and moist soils abundant under temperate wet climate make them attractive candidates (Bungart and Hüttl, 2004; Petzold et al., 2011). In addition, their hardy wood stem is difficult to be damaged by the pigs, thus, their growth is much less compromised, compared to grass (Horsted et al., 2012; Jørgensen et al., 2018). Under North European pedo-climatic conditions, poplars and willows are able to reduce annual nitrate leaching for $>70 \%$ if the land use is changed from cereal crops that on sandy soils in Denmark are estimated to leach $>70 \mathrm{~kg} \mathrm{~N}^{-1}$ (Hermansen et al., 2017; Pugesgaard et al., 2015). To authors' knowledge, no studies have quantified whether and to which extent silvopastoral agroforestry in outdoor pig production affects nitrate leaching.

The overall objective of the present study was to quantify nitrate leaching in individual paddocks with pigs, lactating sows, with and without access to poplar trees relative to a control treatment with no trees, as well as to estimate soil water and $\mathrm{N}$ balances (inputs minus outputs), for an organic pig farm on sandy soil in Denmark. Nitrate leaching was determined from measured soil nitrate concentrations and with the aid of two simulation models for one full hydrological year involving the grazing period of spring-summer with sows and piglets, as well as the autumn-winter-spring period afterwards. It was hypothesised that nitrate leaching is lower in areas with poplars compared to areas with grass, due to a higher $\mathrm{N}$ uptake by the trees prior to and during the leaching season.

\section{Materials and method}

\subsection{Study area and experimental design}

The study was carried out on a private outdoor organic pig farm lo-

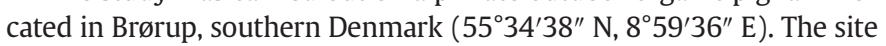
has a coarse sandy soil with an average of $4 \%$ clay, $5 \%$ silt, $89 \%$ sand, and about $2 \%$ organic matter content in the topsoil $(0-25 \mathrm{~cm})$. The experiment included 21 paddocks randomly grouped in three main treatments (thus with seven paddocks, i.e., replicates per treatment): access to trees (AT), no access to trees (NAT) and a control with no trees (NT). The control was designed to represent common practice in outdoor organic pig farming in Denmark. The paddocks with trees were established next to each other on a grass-clover (Lolium perenne-Trifolium repens) field and measured $10 \times 33 \mathrm{~m}$, with $10 \times 6 \mathrm{~m}(20 \%)$ occupied by two rows of poplar trees, either non-fenced (in AT) or fenced (in NAT; see Fig. 1). Nearby on another grass-clover field, the control paddocks (NT) measuring $12 \times 27 \mathrm{~m}$ were established next to each other. In order to facilitate interpretation of results, zones were observed in each paddock: a grass zone, as well as a poplar zone in AT and NAT paddocks, and a control grass zone in the NT paddocks, as illustrated on Fig. 1.

\subsection{Animals and plants management}

Each of the 21 paddocks was occupied by a sow (Sus scrofa domesticus, Landrace $\times$ Yorkshire cross) with, on average, 11.4 piglets per sow. The experiment lasted from April 2015 to April 2016 and included two replicates, i.e., batches of sows, each with 21 snout ringed sows. The first batch occupied the paddocks from May to July 2015 (53 days) and the second batch from August to October 2015 (50 days). Each batch was stratified by parity into seven groups of 


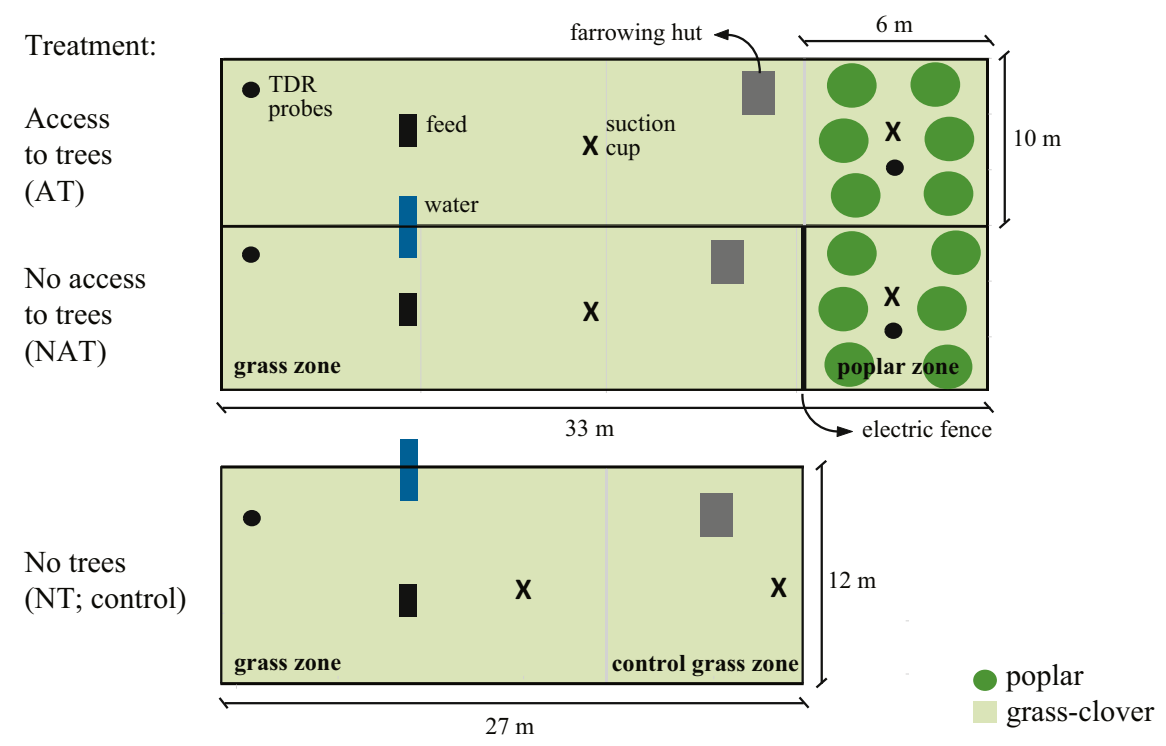

Fig. 1. Scheme of the experimental paddocks and the main treatments in outdoor organic pig farm in Denmark. Scheme not to scale.

three sows allocated to the three treatments, and it involved one-week farrowing, followed by seven-weeks lactation. The farrowing huts (Aframe huts with a basis measuring $4.2 \mathrm{~m}^{2}$ ) were placed directly on the ground and supplied with straw. The sows were provided with an individual feed trough of $0.6 \times 0.6 \mathrm{~m}$ and two neighboring sows shared a water trough of $1.0 \times 0.4 \times 0.2 \mathrm{~m}$. The paddocks were fenced by a one-strand electrified wire that kept each sow within its paddock, but allowed piglets to move below the fence and roam freely between paddocks and in the surroundings and eventually to come back to feed and sleep in the hut with their mother. The sows were provided with a wallow when the air temperature increased above $15^{\circ} \mathrm{C}$. Sows were fed individually, once a day with a standard feed mixture (crude protein content of 14.3\%). The amount of feed for each sow was recorded by the farmer.

For the paddocks with trees, poplar clones OP42 (P. maximowiczii (Henry) $\times$ P. trichocarpa (Torr. et Gray), Taeroe et al., 2015) were planted in 2011 at planting density of 1000 stems ha ${ }^{-1}$ in double rows and a row distance of approximately $3 \mathrm{~m}$. At the start of the experiment, the trees reached 4-years age. The trees had not been pruned prior to the experiment, nor received any fertiliser. In year 2014 before the experiment, spring barley (Hordeum vulgare) with undersown grass-clover (Lolium perenne L. - Trifolium repens L.) was cultivated and the grass-clover was left on the field after the barley harvest. As the experiment was conducted on a certified organic farm, there was no use of synthetic pesticides or fertilisers.

\subsection{Field measurements}

Number and height of the poplar trees, as well as height, coverage and composition (percent-wise contribution of grass and clover) of the grass-clover were measured in each paddock during the batch periods, the latter two determined by visual estimates of a trained observer from the start of the experiment when the grass-clover had reached full coverage. Soil water content (volumetric) was measured with time domain reflectometry (TDR) and by applying a calibration equation developed for Danish soils (Jacobsen and Schjonning, 1993). The TDR probes were installed in four paddocks per treatment in the poplar zone and the grass zone (see Fig. 1). The probes were installed in pairs vertically down to $0.25,0.5$ and $1 \mathrm{~m}$ depth from the surface. Soil water content was measured two to three times monthly from August 2015 until May 2016, except for the control NT treatment where measurements were performed until April 2016. Samples of soil water solution were collected at $1 \mathrm{~m}$ depth using porous ceramic cups
(K100, UMS GmbH, Munich, Germany) installed in duplicates in the middle of the poplar and the grass-clover area in each paddock. From June 2015 until April 2016, soil water samples were collected every second to third week by applying approximately $80 \mathrm{kPa}$ suction on the cups 2-3 days prior to sampling. The nitrate concentrations were determined colorimetrically (Best, 1975).

\subsection{Modelling water balance and nitrate leaching calculation}

Water fluxes were modelled with two models, CoupModel (ver. 5.3.1.1) and Daisy (ver. 5.19), to minimise potential bias by single model and/or modeler. Both are fairly detailed and one-dimensional, deterministic and hydrological coupled heat-energy process-based models able to estimate water fluxes in a soil-plant-atmosphere system. For both models, the water balance comprises fluxes at the surface and in the soil, where the atmosphere and the groundwater constitute the system boundaries. The surface fluxes considered are precipitation (and irrigation, if any; gain), and evapotranspiration (and surface runoff, if any; losses), whereas soil fluxes are deep percolation (drainage; loss) or capillary rise (gain). Soil water dynamics, hence drainage, are modelled by a numerical solution of the Richards's equation. Evapotranspiration is described by the potential evapotranspiration concept according to the FAO Penman-Monteith equation (Allen et al., 1998) and a crop coefficient. Further details about the models are available elsewhere (e.g., Hansen et al., 2012; Jansson and Karlberg, 2011).

Input files necessary to run the models include daily weather data and soil and plant information. For weather, data on air temperature $\left({ }^{\circ} \mathrm{C}\right)$, solar radiation $\left(\mathrm{W} \mathrm{m}^{-2}\right)$, wind speed $\left(\mathrm{m} \mathrm{s}^{-1}\right)$, relative humidity (\%) and precipitation $(\mathrm{mm})$ were obtained for the period January 2014 until December 2016 from the gridded national database of the Danish Meteorological Institute. Precipitation data were corrected to soil surface for possible influence from wind, wetting or evaporation according to Allerup et al. (1997), adding $10-12 \%$ on average to the raw precipitation data. For soil information, texture and organic matter content were parameterised according to the default description for coarse sandy soils in Denmark available in the Daisy model library (Table 1).

For plant information, CoupModel has previously been used in studies with poplar (Georgiadis et al., 2017), whereas the "permanent" vegetation module described by Boegh et al. (2009) was used for Daisy. Although developed for water balance calculations, this module has not been used for simulating poplar. Thus, a global sensitivity analysis was first conducted by the screening method of Morris (1991) in order to determine parameters for calibration. More information and 
Table 1

Soil physical properties for the experimental site in Denmark used in CoupModel and Daisy.

\begin{tabular}{lll}
\hline Soil property & $0-30 \mathrm{~cm}$ & $30-100 \mathrm{~cm}$ \\
\hline Clay (\%) & 3.8 & 2.8 \\
Silt (\%) & 7.2 & 2.3 \\
Sand (\%) & 86.7 & 94.5 \\
Organic matter (\%) & 2.3 & 0.4 \\
Dry bulk density $\left(\mathrm{g} \mathrm{cm}^{-3}\right)$ & 1.5 & 1.5 \\
Carbon-nitrogen ratio & 13 & 14 \\
\hline
\end{tabular}

outputs regarding the sensitivity analysis can be found in the Supplementary information (Description S1, with associated Fig. S1 and Table S1). For both models, the description of poplar and grass-clover contained data of leaf interception capacity, minimum transpiration resistance and root depth, with respective values of $0.1 \mathrm{~mm}, 30 \mathrm{~s} \mathrm{~m}^{-1}$ and $1.0 \mathrm{~m}$ for the poplar, and $0.1 \mathrm{~mm}, 1.0 \mathrm{~s} \mathrm{~m}^{-1}$ and $1.0 \mathrm{~m}$ for the grassclover (Bloemen et al., 2017; Georgiadis et al., 2017; Jones et al., 2017). The height of the plants was set according to the mean measured values. Both models also need input on leaf area index (LAI) development, which vary across the year in broadleaved trees such as poplar. Maximum LAI values are observed during summer and minimum LAI values during winter and early spring as growth ceased once light and temperature requirements are no longer satisfied (Guidi et al., 2008; Liberloo et al., 2006; Zenone et al., 2015). In the current study, LAI variation across the year for poplar was estimated by considering a simple distribution based on Zenone et al. (2015) and visual observations at the experimental site, whereas that of grass-clover was based on the grass-clover coverage measurements during summer, assuming maximum LAI of 2, and decreasing values to 0.5 thereafter (see Fig. S2 in the Supplementary information).

The models were calibrated for each zone in all paddocks with measured soil water content (Fig. 1). CoupModel was calibrated manually by altering the soil hydraulic parameters (see Table S2 in the Supplementary information), whereas Daisy was calibrated by a generic differential evolution algorithm available in Daisy-R platform (Jabloun et al., 2014), which uses the DEoptim function in "DEoptim" package of R. For both models, optimisation criterion was to minimise the root mean squared residuals (RMSR) between simulated and measured water contents at the three soil depths. The simulated daily drainage for each model was used to calculate nitrate leaching for the poplar zones, the grass zones and the control grass zones (Fig. 1). For the paddocks without measured soil water contents (thus, without model setup), the simulated drainage from the other paddocks of the same treatment was used to calculate nitrate leaching, whereas for the control grass zone of the NT paddocks (also without measurements of soil water content), drainage simulated for the grass zone was used. The soil nitrate concentrations were interpolated between measurement dates according to the percolationweighted concentration method similar to that of Lord and Shepherd (1993) in order to obtain daily nitrate leaching $\left[\left(\mathrm{mg} \mathrm{l}^{-1}=\mathrm{mg} \mathrm{dm}^{-3}\right)\right.$ $\left.\times\left(\mathrm{mm} \times 10=\mathrm{m}^{3} \mathrm{ha}^{-1}\right) \times 0.01=\mathrm{kg} \mathrm{ha}^{-1}\right]$. Daily nitrate leaching, as well as evapotranspiration and drainage, were accumulated to annual from 1 April 2015 until 31 March 2016.

\subsection{Data analysis and statistics}

The effects of poplar trees and access to trees on annual evapotranspiration, drainage and nitrate leaching were analysed statistically for each simulation model (CoupModel and Daisy). The nitrate leaching was modelled using a gamma generalised linear mixed models with identity-link (Jorgensen et al., 1996) and a fixed effect representing the combinations of treatment, zone and prediction model, and a random component designed to account for the dependency between observations from the same paddock (for details see Description S2 in the Supplementary material). The means of the predictions of nitrates leaching obtained by the two simulation models were inferred for each combination of treatment and zone by defining a suitable contrast in the gamma mixed model. Neither the evapotranspiration nor the drainage predictions could be adequately modelled by a generalised linear mixed model defined with a standard probability distribution. Therefore, nonparametric Kruskal-Wallis tests were used to compare evapotranspiration and drainage medians of the different combinations of treatment and zone (separate analyses were made for the two simulation models and their median). The confidence intervals for the reported medians of evapotranspiration and drainage were inferred using non-parametric bootstrap (with 10.000 bootstrap samples). The analyses were conducted in R (R Core Team, 2013), specifically with the packages "Ime4" for adjusting generalised linear mixed models and "pairwiseComparisons" (Labouriau, unpublished) for making inferences on the contrasts, performing post-hoc analyses and calculating Wald and bootstrap confidence intervals. The $p$-values used in the post-hoc analyses were adjusted for multiple comparisons using the false discovery rate method (Benjamini and Yekutieli, 2001).

\subsection{Nitrogen balance}

Surface $\mathrm{N}$ balance $\left(\mathrm{kg} \mathrm{N}^{-1}\right)$ was estimated at paddock level for each treatment as the difference between input and output (Nielsen and Kristensen, 2005):

Surface balance $=N_{\text {inputs }}($ feed, straw, fix, atm $)-N_{\text {output }}($ pig $)$

where feed is the measured mean feed (Table 2) with assumed $14.3 \%$ crude protein with $16 \% \mathrm{~N}$, straw is $\mathrm{N}$ from straw provided to the huts with $5 \mathrm{~kg} \mathrm{~N} \mathrm{ha}^{-1}$ (Nielsen and Kristensen, 2005), fix is biological N fixation by the grass-clover of $30 \mathrm{~kg} \mathrm{~N} \mathrm{ha}^{-1}$ (Jakobsen et al., 2015) and atm is atmospheric deposition of $16 \mathrm{~kg} \mathrm{~N}^{-1}$ (Halberg et al., 2010).

The output pig is $\mathrm{N}$ in weaned piglets with assumed $25 \mathrm{~g} \mathrm{~N} \mathrm{~kg}^{-1}$ (Poulsen and Kristensen, 1997) and calculated according to the measured number of piglets (Table 2). Soil N balance was calculated as Surface balance minus the sum of $\mathrm{N}$ losses by leaching, ammonia $\left(\mathrm{NH}_{3}\right)$ and nitrous oxide $\left(\mathrm{N}_{2} \mathrm{O}\right)$ emissions from grazing and crop residues, nitrogen oxides $\left(\mathrm{NO}_{\mathrm{X}}\right)$ and dinitrogen $\left(\mathrm{N}_{2}\right)$, estimated using emission factors (Table 3 ). $\mathrm{N}$ loss due to surface runoff was disregarded as the soil surface was flat ( $<2 \%$ slope).

\section{Results}

\subsection{Weather characteristics}

Compared to the long term (1985-2014) annual mean of $8.5^{\circ} \mathrm{C}$ and $1074 \mathrm{~mm}$ for temperature and precipitation, respectively, years 2015 and 2016 were warmer, with corresponding temperatures of 9.1 and $9.2^{\circ} \mathrm{C}$, and 2015 was wetter $(1150 \mathrm{~mm})$ than 2016 (767 mm). From April 2015 to April 2016, however, precipitation was very close to the long-term mean of $1075 \mathrm{~mm}$. The other weather variables, i.e., global radiation, wind speed and relative humidity of 3730 and $3756 \mathrm{MJ} \mathrm{m}^{-2}, 4.8$ and $4.2 \mathrm{~m} \mathrm{~s}^{-1}$, and 84.4 and $84.7 \%$, for 2015 and 2016, respectively, did not differ much from the corresponding long term means of $3580 \mathrm{MJ} \mathrm{m}^{-2}, 4.2 \mathrm{~m} \mathrm{~s}^{-1}$ and $84 \%$.

\subsection{Plant and soil observations}

In the poplar zone of AT and NAT treatments, the number of trees varied between five and six, though in few paddocks only three to four trees were present (Fig. 2). The height of the trees also varied between 5 and $7.8 \mathrm{~m}$. Both AT and NAT treatments had, on average, five trees with similar height of about $6 \mathrm{~m}$. In all treatments, grass-clover coverage was about $90 \%$ from May until September 2015, being slightly higher in NT compared to AT and NAT treatments (Fig. 3). Grass-clover coverage started to decline from September to October, coinciding with the time when the second batch of sows left the paddocks. Grass-clover height followed similar dynamics as coverage, being higher in NT 
Table 2

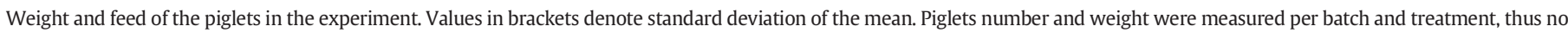
measure of variation is reported.

\begin{tabular}{|c|c|c|c|c|c|c|}
\hline & \multicolumn{3}{|l|}{ First batch (53 days) } & \multicolumn{3}{|c|}{ Second batch (50 days) } \\
\hline & Access to trees (AT) & No access to trees (NAT) & $\begin{array}{l}\text { No trees } \\
\text { (NT, control) }\end{array}$ & Access to trees (AT) & No access to trees (NAT) & $\begin{array}{l}\text { No trees } \\
\text { (NT, control) }\end{array}$ \\
\hline $\begin{array}{l}\text { Feed } \\
\left(\text { kg sow }^{-1} \text { day }^{-1}\right)\end{array}$ & $8.9(5.1)$ & $8.8(4.8)$ & $8.9(4.8)$ & $7.2(3.7)$ & $6.7(3.8)$ & $7.3(3.6)$ \\
\hline Number of piglets & 73 & 70 & 80 & 75 & 83 & 74 \\
\hline Piglets weight $\left(\mathrm{kg} \mathrm{piglet}^{-1}\right)$ & 13.2 & 15.0 & 11.1 & 10.7 & 11.7 & 10.4 \\
\hline
\end{tabular}

compared to AT and NAT during sow occupation, but thereafter treatment differences leveled off with a decreasing trend (Fig. 3).

The soil water content measured at three depths $(0.25,0.5$ and $1 \mathrm{~m})$ are shown in Fig. 4. Overall, the dynamics followed the rainfall events and were similar between zones and treatments. Somewhat higher soil water contents were observed in the grass zone compared to the poplar zone. In the poplar zone, soil water content was consistently higher for AT (13-22 vol\%) compared to NAT treatment (8-16 vol\%), which was particularly evident at 0.5 and $1 \mathrm{~m}$ depths. The highest soil water content of 18-22 vol\% was observed in December 2015 and April 2016. In the grass zone, AT and especially NAT had lower soil water contents compared to NT, and this was especially evident at $1 \mathrm{~m}$ depth throughout most of the study period. The highest soil water contents in the grass zone of $18-24 \mathrm{vol} \%$ were observed for AT and NT in September and November 2015, i.e., following rainfall events (Fig. 4).

Soil nitrate concentrations measured at $1 \mathrm{~m}$ depth responded markedly to treatment by exhibiting different magnitude and characteristic peaks linked to high drainage, i.e. downward transport of soil nitrate. However, the time and the magnitude of the peaks differed in relation to treatment. In the poplar zone, AT and NAT treatments illustrated similar dynamics of nitrate concentrations with consistently low magnitude (between 1 and $10 \mathrm{mg} \mathrm{NO}_{3}-\mathrm{Nl}^{-1}$ ) from June to November (Fig. 5). Thereafter, nitrate concentrations increased to about 23 and $11 \mathrm{mg} \mathrm{NO}_{3}-\mathrm{N} \mathrm{I}^{-1}$ for AT and NAT, respectively, and the peak for AT occurred earlier compared to NAT. For the control NT treatment, nitrate concentrations in control grass zone (closest to the hut) were higher from the beginning and more variable, rising to almost $200 \mathrm{mg} \mathrm{NO}_{3}-\mathrm{N}^{-1}$ in some paddocks during November-December 2015, before steadily decreasing in all paddocks. In the grass zone, there were opposite trends in the magnitude of nitrate concentrations between treatments: the treatments with trees (AT, NAT) hade higher values compared to the control (NT) and steadily increased from June until December 2015, reaching about 55-65 and 37-44 $\mathrm{mg} \mathrm{NO}_{3}-\mathrm{N}^{-1}$, for AT and NAT, respectively. In the grass zone of NT treatment, however, low nitrate concentrations of 10-14 $\mathrm{mg} \mathrm{NO}_{3}-\mathrm{N}^{-1}$ were measured, except for the winter peak of $27 \mathrm{mg} \mathrm{NO}_{3}-\mathrm{N} \mathrm{I}^{-1}$, on average.

\subsection{Simulating soil water dynamics, evapotranspiration and drainage}

The two calibrated models were able to reproduce the measured dynamics of soil water content at various depths (Fig. 6). The simulations were satisfactory for $0.5 \mathrm{~m}$ depth (mean observed $=14.2 \%$, mean simulated $=14.4$ and 14.3 vol\% for CoupModel and Daisy, respectively) and $1 \mathrm{~m}$ depth (mean observed $=14.2 \mathrm{vol} \%$, mean simulated $=14.1$ and 14.7 vol\% for CoupModel and Daisy, respectively), whereas the models were less accurate for $0.25 \mathrm{~m}$ and tended to slightly to moderately underestimate the measured soil water contents (mean observed $=16.2 \mathrm{vol} \%$, mean simulated $=12.9$ and $15.6 \mathrm{vol} \%$ for CoupModel and Daisy, respectively). However, the difference between measured and simulated soil water contents across the whole soil profile was relatively small (mean observed $=14.5 \mathrm{vol} \%$, mean simulated $=13.9$ and 13.8 vol\% for CoupModel and Daisy, respectively), with RMSR of 3.1 and 3.6 vol\% for CoupModel and Daisy, respectively.

Evapotranspiration and drainage were simulated by CoupModel and Daisy per zone and treatment, and their medians are shown in Table 4. Overall, both simulation models, as well as the median of the two models, showed higher evapotranspiration and lower drainage for poplar compared to grass-clover. CoupModel yielded consistent and significant median differences in relation to crop, with higher evapotranspiration (560-569 mm) and lower drainage (565-576) for poplar compared to grass-clover (251-255 for evapotranspiration and 956-957 mm for drainage). Similarly, Daisy simulated evapotranspiration for poplar (489-498 mm) was significantly higher than that of grass-clover (405-433 mm), whereas poplar drainage (628-635 mm) was significantly lower than grass-clover drainage (about $702-726 \mathrm{~mm}$ ). Also, for the grass zone, Daisy simulated evapotranspiration and drainage for the control NT were significantly different than for the other treatments. The median results of the two models showed about 525-534 mm evapotranspiration and about 590-607 mm drainage for poplar, whereas corresponding values for grass-clover were $328-344 \mathrm{~mm}$ and $829-841 \mathrm{~mm}$, with variation attributed to the main treatment (Table 4).

\subsection{Nitrate leaching and nitrogen balances}

Overall, the mean nitrate leaching, modelled by gamma-distribution linear mixed effects model, was significantly lower in the poplar zone compared to the grass- and control grass zones for both simulation models and all treatment (Table 4). For the poplar zone, both models and their mean agreed for somewhat higher leaching in AT compared to NAT, though differences were insignificant. However, leaching was several-fold lower in the poplar zone compared to the grass zone. In

Table 3

Factors for estimation of emissions from the organic pig farm in Denmark.

\begin{tabular}{|c|c|c|c|c|}
\hline Type & Source & Amount & Factor & Reference \\
\hline \multirow[t]{2}{*}{$\mathrm{NH}_{3}-\mathrm{N}$} & Grazing & $\mathrm{kg} \mathrm{N} \mathrm{ha}^{-1}$ year $^{-1}$ in feed & 0.13 & Eriksen et al. (2002) \\
\hline & Crop residues & $\mathrm{kg} \mathrm{N} \mathrm{ha}^{-1}$ year $^{-1}$ & 0.5 & Gyldenkaerne and Albrektsen (2008) \\
\hline \multirow[t]{2}{*}{$\mathrm{N}_{2} \mathrm{O}-\mathrm{N}$ direct } & Grazing & kg N deposited at pasture ${ }^{a}$ & 0.02 & $\operatorname{IPCC}(2006)$ \\
\hline & Crop residues & $\mathrm{kg} \mathrm{N}^{-1}$ year $^{-1}$ in crop residues ${ }^{\mathrm{b}}$ & 0.01 & IPCC (2006) \\
\hline $\mathrm{NOx}$ & Nitrogen oxides & $\mathrm{kg} \mathrm{N} \mathrm{ha}^{-1}$ year $^{-1}$ & $\mathrm{NH}_{3}-\mathrm{N} / 88 * 12$ & Nemecek and Kägi (2007) \\
\hline \multirow{2}{*}{$\mathrm{N}_{2}-\mathrm{N}$ direct } & Manure & $\mathrm{kg} \mathrm{N} \mathrm{ha}^{-1}$ year $^{-1}$ in manure ${ }^{\mathrm{a}}$ & 0.06 & Vinther and Hansen (2004) \\
\hline & Crop residues & $\mathrm{kg} \mathrm{N} \mathrm{ha}^{-1}$ year $^{-1}$ in crop residues ${ }^{\mathrm{b}}$ & 0.03 & Vinther and Hansen (2004) \\
\hline
\end{tabular}

${ }^{a}$ Calculated as feed - pig + grass-clover uptake by sow, the latter assumed from $500 \mathrm{~kg} \mathrm{ha}^{-1}$ grass clover dry matter, with $45 \%$ carbon (C), and C/N ratio of 10 , which equates to $23 \mathrm{~kg} \mathrm{~N} \mathrm{ha}^{-1}$.

b Calculated as $206 \mathrm{~kg} \mathrm{~N} \mathrm{ha}^{-1}$ total (above- and belowground) using allometric relations. 

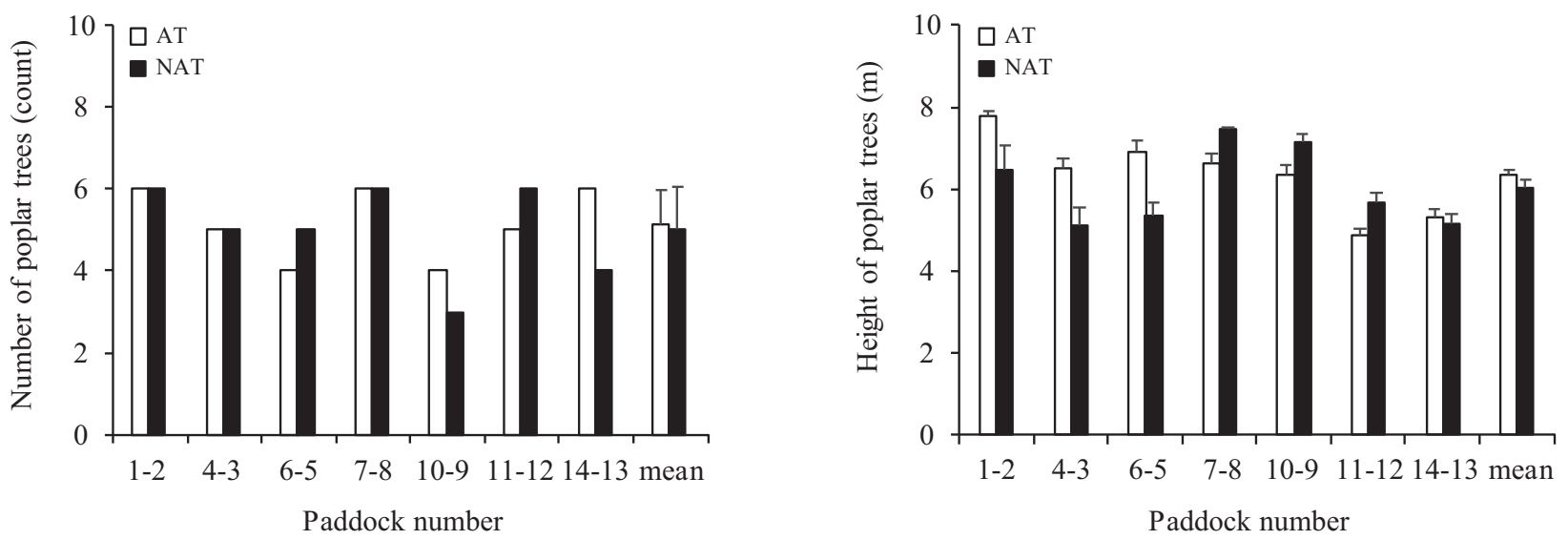

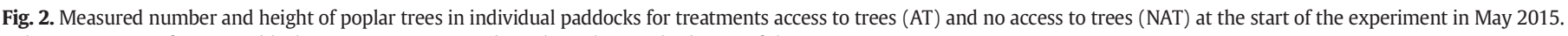
Values are means of seven paddocks per treatment, error bars show the standard error of the mean.

the grass zone, leaching tended to be higher for AT compared to NAT and NT, but differences were only significant for the Daisy model results that reported lower leaching in NT compared to NAT and AT treatments.

Estimated $\mathrm{N}$ balances $\left(\mathrm{kg} \mathrm{ha}^{-1}\right)$ for each of the three treatments are presented in Table 5. Import of $\mathrm{N}$ in feed was the major input in all three balances, although it was slightly reduced for AT and NAT with 576 and $564 \mathrm{~kg} \mathrm{~N} \mathrm{ha}^{-1}$ for AT and NAT, respectively, compared to the NT (600 kg N ha $\left.{ }^{-1}\right)$. The number of weaned piglets was lower in NT compared to AT and NAT and, combined with a higher feed input, this resulted in $28 \%$ exported $\mathrm{N}$ for the control NT treatment, compared to 30 and $36 \%$ exported $\mathrm{N}$ for the AT and NAT treatment. The surface $\mathrm{N}$ balance was larger for the NT treatment ( $468 \mathrm{~kg} \mathrm{~N} \mathrm{ha}^{-1}$ ) compared to the AT (436 kg N ha ${ }^{-1}$ ) and the NAT (397 $\mathrm{kg} \mathrm{N} \mathrm{ha}^{-1}$ ) treatments. When losses by leaching, denitrification and volatilisation were accounted for, soil $\mathrm{N}$ balances were positive for all treatments and did not differ markedly between the treatments, though NAT had the largest value compared to AT and NT that were similar with each other (Table 5).

\section{Discussion}

\subsection{Nitrogen leaching from the studied silvopastoral agroforestry systems}

The risk for nitrate leaching is one of the main arguments against outdoor pig production. Overall, this study reports high nitrate leaching values in the grass zones (Table 4), despite high cover of grass-clover during sow occupation (Fig. 3). Outdoor pig farming studies under the same or similar pedo-climatic conditions also show high nitrate leaching of up to $200 \mathrm{~kg} \mathrm{~N}^{-1}$ (e.g., Eriksen et al., 2002; Williams et al., 2000). Taken as a weighted mean of the poplar and the grass zones as an approximation for the paddocks, the largest leaching of $206 \mathrm{~kg} \mathrm{~N} \mathrm{ha}^{-1}$ was obtained for the control NT treatment, whereas 175 and $101 \mathrm{~kg} \mathrm{~N} \mathrm{ha}^{-1}$ were estimated for the AT and the NAT treatments, respectively. This corresponded to 34,18 and $30 \%$ of the feed input, for NT, AT and NAT, respectively. These results indicate that inclusion of poplar trees in paddocks for lactating sows bare potential to reduce nitrate leaching. However, it should be mentioned that a paddock level values for nitrate leaching are uncertain as $20 \%$ of tree cover (as in the present study) is probably not enough to reduce losses on a mean area basis. Additional management strategies are needed, e.g. reduction in stocking densities (Jørgensen et al., 2018), and/or a larger tree area combined with harvesting of leaves during summer or autumn to increase poplar nutrient uptakes.

Inclusion of poplars in outdoor pig production is a relatively new method driven primarily by the increased and concurrent need for biomass for bioenergy in Europe (Jørgensen et al., 2018). The nitrate leaching for the poplar zone in the AT treatments did not differ significantly from that in the NAT treatments. The presence of poplars reduced the soil nitrate concentrations throughout the entire year compared to the control (Fig. 5). Measurements of soil mineral N (0-50 cm) during autumn after sow occupation showed comparable values in the zones with trees and the zones with grass-clover (Jakobsen et al., 2018). Given the correlation between autumn soil mineral $\mathrm{N}$ and potential nitrate leaching that some studies found (e.g., Williams et al., 2005), the poplars probably took up soil nitrate effectively: 5-7 $\mathrm{Mg} \mathrm{DM} \mathrm{ha}^{-1}$ poplar biomass with $\mathrm{N}$ content of $10 \mathrm{mg} \mathrm{g}^{-1} \mathrm{DM}$ ( 3 and $7 \mathrm{mg} \mathrm{N} \mathrm{g} \mathrm{DM}$ for stem and braches, respectively), as approximated from Georgiadis et al. (2017), equates to $50-70 \mathrm{~kg} \mathrm{~N} \mathrm{ha}^{-1}$ taken up by the poplars. While future studies may accurately measure $\mathrm{N}$ uptake by poplars and grass-clover in organic pig farms, the results support the hypothesis
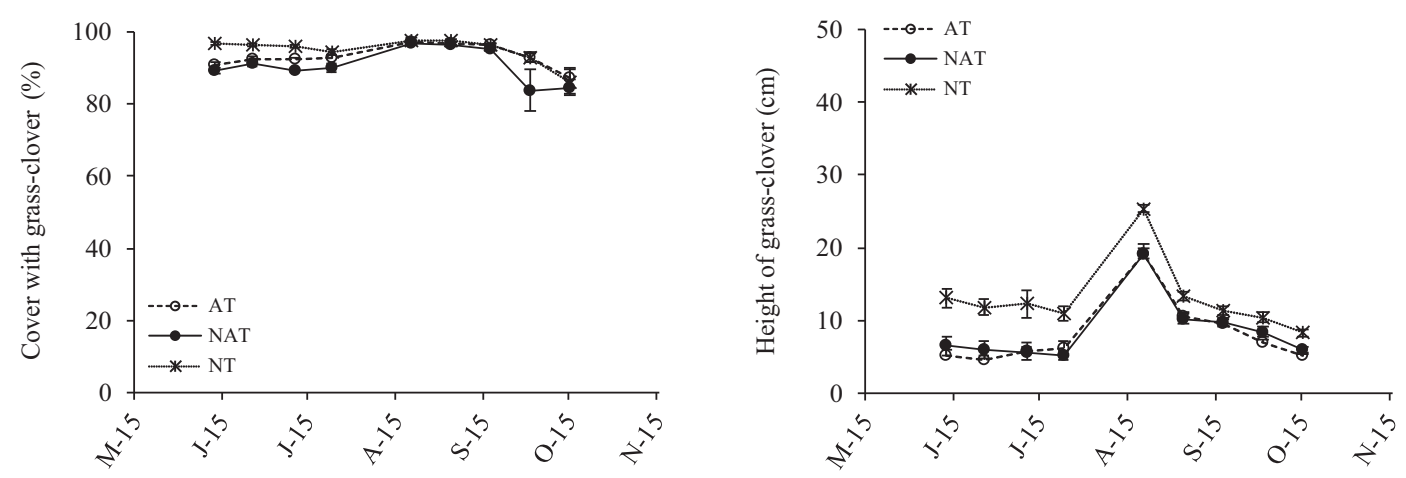

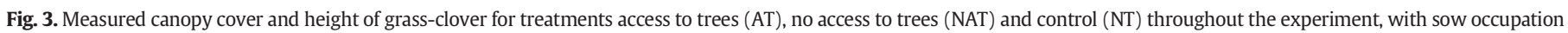
during May-July 2015 and August-October 2015. Values are means of seven paddocks per treatment, error bars show the standard error of the mean. 

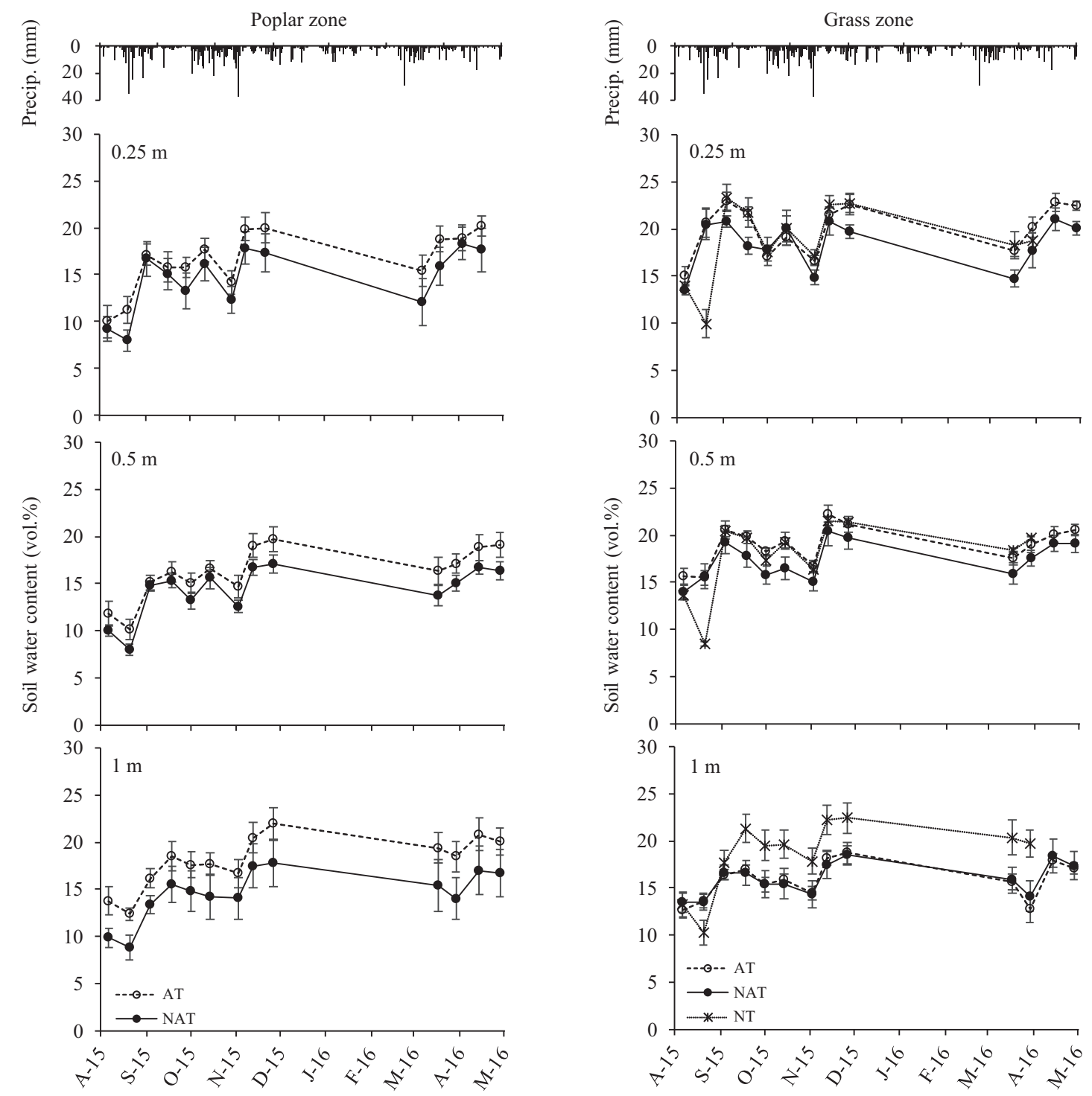

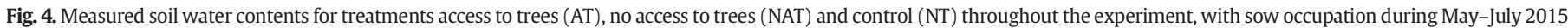

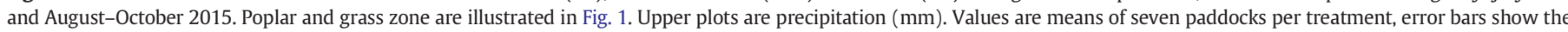
standard error of the mean.

that nitrate leaching is lower in areas with trees compared to grassclover, due to a higher $\mathrm{N}$ uptake by the trees prior to and during the leaching season.
Although the grass-clover cover was kept high during the experiment (Fig. 3) due to the 3-weeks break between the two batches, allowing for a proper re-growth, this zone was characterised by high
Poplar/control grass zone

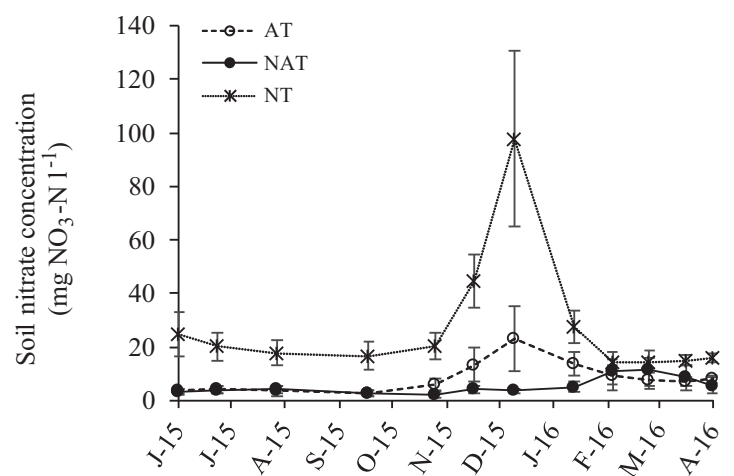

Grass zone

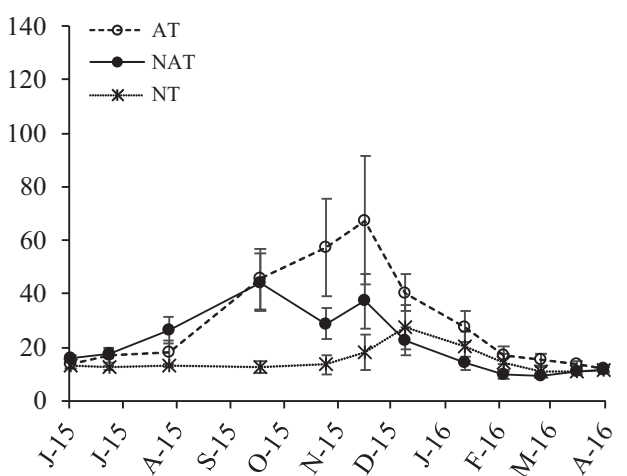

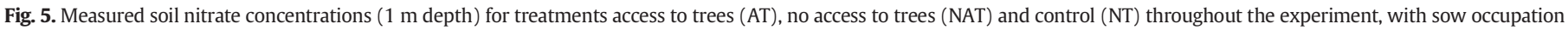

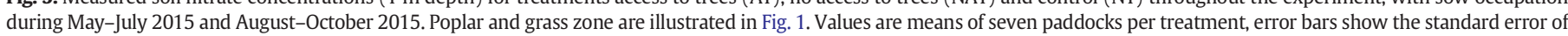
the mean. 

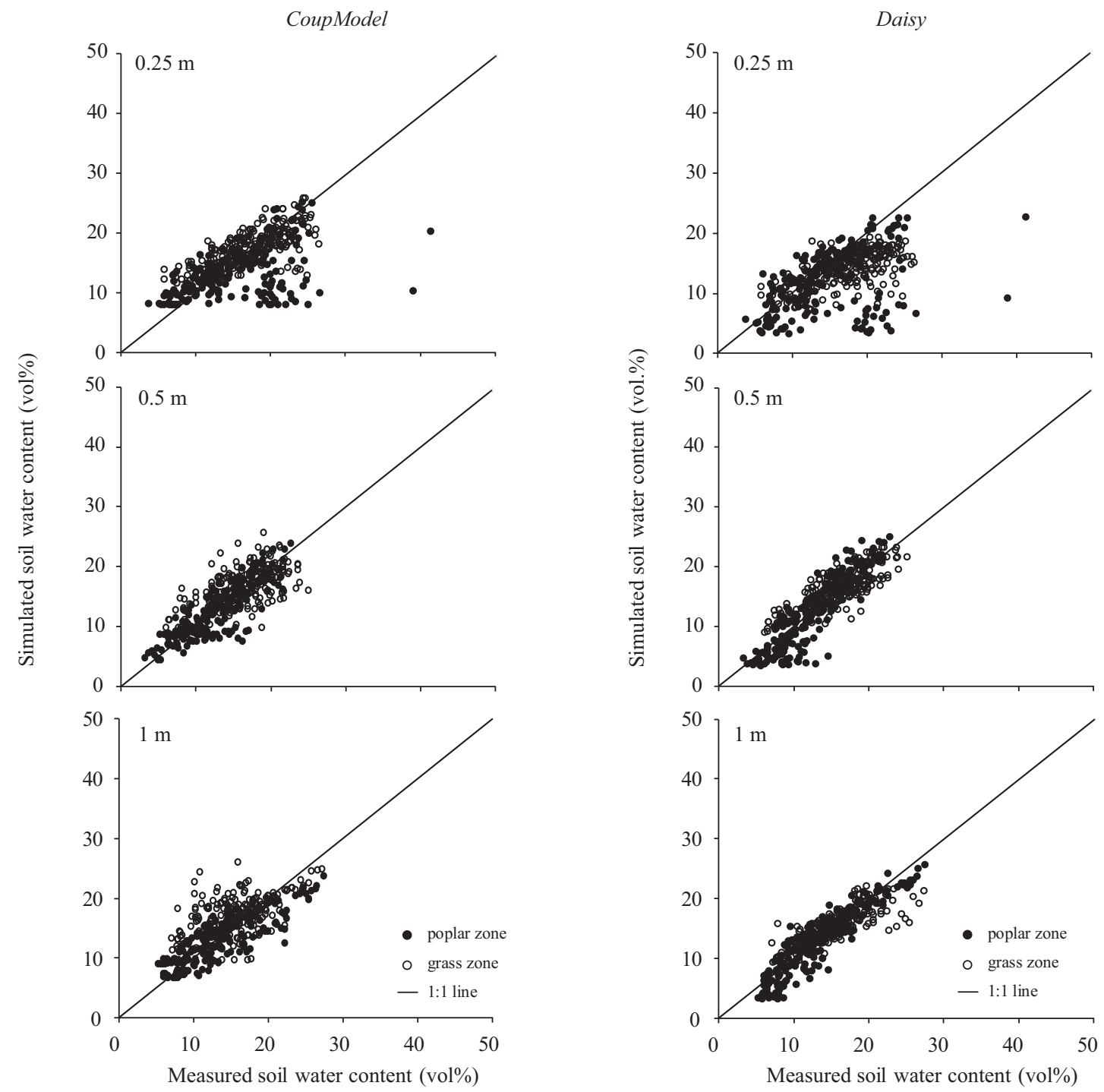

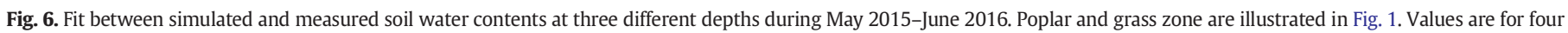
paddocks per zone and model.

Table 4

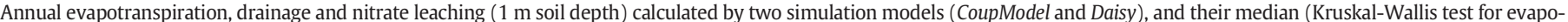

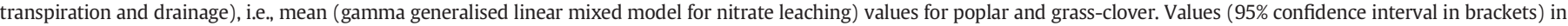
columns per model with different letters are significantly different at $p \leq 0.05$.

\begin{tabular}{|c|c|c|c|c|c|c|}
\hline Variable & Treatment & Zone & Plant & CoupModel & Daisy & Median \\
\hline \multirow{6}{*}{$\begin{array}{l}\text { Evapotranspiration } \\
(\mathrm{mm})\end{array}$} & Access to trees (AT) & \multirow[t]{2}{*}{ Poplar zone } & Poplar & $569(564-574) a$ & $498(488-574) a$ & $534(528-569) a$ \\
\hline & No access to trees (NAT) & & Poplar & $560(551-561) a$ & $489(486-561) a$ & $525(518-561) a$ \\
\hline & No trees (NT, control) & Control grass zone & Grass-clover & $255(254-255) c$ & $433(425-455) c$ & $344(340-354) b$ \\
\hline & Access to trees (AT) & \multirow[t]{3}{*}{ Grass zone } & Grass-clover & $252(246-254) c$ & $405(389-453) b c$ & $328(318-354) b$ \\
\hline & No access to trees (NAT) & & Grass-clover & $251(247-375) c$ & 408 (402-417)b & 332 (325-389)b \\
\hline & No trees (NT, control) & & Grass-clover & $255(254-255) c$ & $433(425-455) c$ & $\begin{array}{l}344(340-354) b \\
\text { Median }\end{array}$ \\
\hline \multirow{6}{*}{$\begin{array}{l}\text { Drainage } \\
(\mathrm{mm})\end{array}$} & Access to trees (AT) & \multirow[t]{2}{*}{ Poplar zone } & Poplar & $565(536-575) a$ & 628 (550-633)a & 590 (562-599)a \\
\hline & No access to trees (NAT) & & Poplar & $576(575-583) a$ & 635 (574-639)a & 607 (575-608)a \\
\hline & No trees (NT, control) & Control grass zone & Grass-clover & 956 (956-957)b & 702 (669-709)b & $829(813-833) b$ \\
\hline & Access to trees (AT) & \multirow{3}{*}{ Grass zone } & Grass-clover & 957 (956-957)b & $726(675-744) b c$ & $841(816-851) b$ \\
\hline & No access to trees (NAT) & & Grass-clover & 957 (837-965)b & $719(714-732) c$ & $837(785-843) b$ \\
\hline & No trees (NT, control) & & Grass-clover & 956 (956-957)b & 702 (669-709)b & $\begin{array}{l}829(813-833) b \\
\text { Mean }\end{array}$ \\
\hline \multirow{6}{*}{$\begin{array}{l}\text { Nitrate leaching } \\
\left(\mathrm{kg} \mathrm{N} \mathrm{ha}^{-1}\right)\end{array}$} & Access to trees (AT) & \multirow[t]{2}{*}{ Poplar zone } & Poplar & $70(19-121) a b$ & $71(20.5-122) a b$ & $71(23-118) a b$ \\
\hline & No access to trees (NAT) & & Poplar & $32(1-82) a$ & $32(1-82) a$ & $32(17-81) a$ \\
\hline & No trees (NT, control) & Control grass zone & Grass-clover & 321 (224-419)c & $257(172-342) c$ & $289(222-356) c$ \\
\hline & Access to trees (AT) & \multirow[t]{3}{*}{ Grass zone } & Grass-clover & $317(222-412) c$ & $253(175-331) \mathrm{cd}$ & $285(221-349) c$ \\
\hline & No access to trees (NAT) & & Grass-clover & $197(125-270) \mathrm{bc}$ & 153 (90-217)bcd & $175(116-234) b c$ \\
\hline & No trees (NT, control) & & Grass-clover & $154(98-210) b$ & 123 (70-175)abd & $138(90-187) b$ \\
\hline
\end{tabular}


Table 5

Annual nitrogen balances $\left(\mathrm{kg} \mathrm{N} \mathrm{ha}^{-1}\right)$ for the three treatments in the organic pig farm in Denmark.

\begin{tabular}{llll}
\hline & $\begin{array}{l}\text { Access to trees } \\
(\mathrm{AT})\end{array}$ & $\begin{array}{l}\text { No access to trees } \\
\text { (NAT) }\end{array}$ & $\begin{array}{l}\text { No trees (NT; } \\
\text { control) }\end{array}$ \\
\hline Feed & 576 & 564 & 600 \\
Straw & 5 & 5 & 5 \\
Atm. deposition & 16 & 16 & 16 \\
Clover fixation & 30 & 30 & 30 \\
Total input & 627 & 615 & 651 \\
Weaned piglets & 191 & 219 & 183 \\
Surface balance & 436 & 397 & 468 \\
N efficiency (\%) & 31 & 36 & 28 \\
N losses & & & \\
Ammonia & & & 78 \\
$\quad$ Grazing & 75 & 73 & 15 \\
$\quad$ Crop residues & 15 & 15 & 9 \\
Nitrous oxide & & 7 & 2 \\
$\quad$ Grazing & 8 & 2 & 13 \\
$\quad$ Crop residues & 2 & 12 & 26 \\
Nitrogen oxides & 12 & & 6 \\
Dinitrogen & & 22 & 206 \\
$\quad$ Manure & 24 & 6 & 113 \\
Crop residues & 6 & 101 & \\
Leaching & 175 & 157 & \\
Soil balance & 118 & & \\
\hline
\end{tabular}

a Calculated as ratio of weaned piglets (output) to total input.

b Values per treatment taken as a weighted average of the two zones and models (Table 3).

leaching. The area around the hut has been reported as one of the most problematic nutrient "hotspot", with soil nitrate concentrations of almost $300 \mathrm{NO}_{3}-\mathrm{N}^{-1}$ (e.g., Eriksen, 2001). In the current experiment, soil samples collected at 60 grid points in one randomly chosen paddock within each treatment supported high $\mathrm{N}$ loads in the area of the hut (Jakobsen et al., 2018). The suction cups installed in the poplar zone were relatively close to the hut, but those located in the control grass zone of NT were even closer. The latter is probably the reason for the large difference in both soil nitrate concentrations (Fig. 5) and leaching (Table 4) between the two grass zones (more than doubled in control grass zone compared to grass zone). This complicates a direct comparison between paddocks with trees (AT and NAT) and the control paddocks (NT), but it does emphasise the importance of taking the location of the hut into account when designing paddocks for outdoor sows.

\subsection{Other nitrogen losses and nitrogen balances}

For the grazing season, $80-87 \mathrm{~kg} \mathrm{~N} \mathrm{ha}^{-1}$ were calculated for the two batches as excreted by the pigs (ammonium + nitrate; Table 5). For comparison, Olsson et al. (2014) reported about $130 \mathrm{~kg} \mathrm{~N} \mathrm{ha}^{-1}$ excreted by finishing pigs with access to pasture on an organic farm in Sweden. The $\mathrm{N}$ on pasture during the grazing season is partially utilised by the plants, partially metabolised and mineralised in soil, and the risk for $\mathrm{N}$ leaching during the growing season is limited as long as the plant surface is viable. The only Danish study with outdoor pig farming on sandy soil with grass and the same stocking density as this study (i.e., 1 sow $330 \mathrm{~m}^{-2}$, or 32 sows ha-1) reported nitrate leaching of 141-308 $\mathrm{kg} \mathrm{N} \mathrm{ha}^{-1}$ determined from measured soil nitrate concentrations and modelled drainage (Eriksen et al., 2002). The same study also reported $114 \mathrm{~kg} \mathrm{~N}^{-1}$ loss via ammonia volatilisation measured with an atmospheric mass balance technique, which is comparable to the roughly $90 \mathrm{~kg} \mathrm{~N} \mathrm{ha}^{-1}$ reported in this study (Table 5). Ammonia volatilisation mostly occurs due to urination and thus is largely restricted to the grazing period. In addition to these $\mathrm{N}_{2} \mathrm{O}$ emission, $\mathrm{N}_{2}$ emission is another possible loss pathway following denitrification. Monaghan and Barraclough (1993) measured $\mathrm{N}_{2}$ losses that were 13 times greater than $\mathrm{N}_{2} \mathrm{O}-\mathrm{N}$ fluxes from a clay loam soil treated with dairy cattle urine. However, ammonia volatilisation, as well as denitrification was not substantially different between treatments (Table 5), and nitrate leaching was probably the main sink for inorganic N.

For a temperate humid climate and on a short (annual) timescale, the results clearly showed higher $\mathrm{N}$ efficiency for the treatments with poplars compared to the control treatment (Table 5). It should be mentioned that the residues of grass-clover are rich in $\mathrm{N}$, which will eventually be released; therefore, under the studied conditions, replacing grass-clover with pure grass in the paddocks might be a more viable option, although that would not necessarily tighten the $\mathrm{N}$ balance as $\mathrm{N}$ in feed has to be closely controlled (Halberg et al., 2010). Another possible option is seasonal production (May-September) of lactating pigs on grass field followed by a nutrient-demanding main winter cereal crop, such as wheat, barley or rye. Regarding the poplars, noteworthy is that they can also provide additional animal benefits in terms of shade during hot periods and wind protection during cooler autumn months. Furthermore, they can be harvested to produce wood, packaging components and woodchips for energy use, or utilised within the farm as bedding/rooting material for the pigs. Other benefits include increased soil quality in terms of nutrient cycling efficiency, as the roots of poplars can function as a buffer for reducing nutrient leaching below the root zone of alley crops (Bergeron et al., 2011), and also the root zone soil have greater earthworm densities due to greater litter contributions and its rapid decomposition (Thevathasan et al., 2012).

\subsection{Simulated water balance and modelling uncertainties}

Simulated annual evapotranspiration for the poplar was 560-569 and 489-498 mm for CoupModel and Daisy, respectively (Table 4). For comparison, Jassal et al. (2013) measured 440 mm annual evapotranspiration for poplar $(P$. deltoides $\times P$. petrowskyana) on clay loam in Canada, whereas Fischer et al. (2013) measured 344-549 mm for poplar (P. nigra $\times$ P. maximowiczii) in the Czech Republic, attributing the variation to period, age and height of the stands, along with leaf area index and state of the canopy closure. Other studies involving simulation models reported 221 to $569 \mathrm{~mm}$ annual evapotranspiration for poplar characterised by different development stages (Georgiadis et al., 2017), or at sites with lower precipitation and young poplars that had either not reached full canopy closure (Bloemen et al., 2017), or with clayey sandy soil with low nutrient status (Bungart and Hüttl, 2004). There is also an uncertainty element in comparing plant evapotranspiration between studies due to differences in clone (parentage), field management and time periods. The LAI values used for poplar (Fig. S2 in the Supplementary information) felt within the range of 1-5 $\mathrm{m}^{2} \mathrm{~m}^{-2}$ for early-established SRC plantations of poplar (Liberloo et al., 2006; Zenone et al., 2015). For grass-clover, the LAI dynamics in autumn was reduced to mimic disturbances from the sows and piglets and gradual decline in canopy cover during winter. As a result, simulated annual evapotranspiration for grass-clover was 250 and $400 \mathrm{~mm}$ for CoupModel and Daisy, respectively (Table 4), which is lower than about $500 \mathrm{~mm}$ typically reported for grass-clover on coarse sandy soil in Denmark (e.g., Pugesgaard et al., 2015). This is also because grassclover fields in other studies are undisturbed, cut and grown under potential conditions. Even if the values of LAI for grass-clover in spring and autumn are increased, the results would not change notably as the simulation outputs were not sensitive to change in this parameter values (Fig. S1 in the Supplementary information).

The accumulated drainage simulated by Daisy of $620-723 \mathrm{~mm}$ is within the typical values for coarse sandy soils reported by other studies (Askegaard et al., 2005; Eriksen, 2001; Manevski et al., 2015), whereas CoupModel simulated $568-958 \mathrm{~mm}$, which was probably overestimated at the higher end. Even though the two models generate relatively similar predictions of the nitrate leaching, they do produce rather different predictions of drainage and evapotranspiration (as reported in Table 4). One reason is the soil parameterisation (e.g., two versus three horizons for Daisy and CoupModel, respectively). Due to the single year nature of 
the study, it is not possible to further discuss in more detail under which circumstances the two methods produce different results. The models were calibrated using different methodologies and averaging their results aimed to minimise variation (or error) due to model and/or modeler (Confalonieri et al., 2016). Yet, averaging simulation outputs from different models that used identical calibration data is not of statistical importance, despite recent studies reporting that mean/median of models ensemble compensates for individual model errors (Martre et al., 2015; Yin et al., 2017a; Yin et al., 2017b). This is because models using the same data for their optimisation are not statistically independent variables. As discussed in Martre et al. (2015), it can be questioned whether the superiority of models' average results to describe agroecosystem variables is robust compared to individual models.

\section{Conclusion}

This study investigated the potential of silvopastoral agroforestry for reducing nitrate leaching in outdoor organic pig farming under temperate climate and sandy soils, experimentally and with the support of simulation modelling, thereby also providing insights into the water balance. According to the results, it is feasible to control nitrate leaching from outdoor pig farming in Denmark through introducing poplar trees in grass-clover paddocks. The results showed a $75 \%$ reduction in nitrate leaching from zones with poplar trees compared with leaching from zones with grass-clover. However, additional measures are needed to reduce $\mathrm{N}$ losses on a mean area basis in paddocks with only $20 \%$ tree cover. Also, measurements on the actual $\mathrm{N}$ uptake by the poplar and the grass-clover would facilitate the optimisation of the systems in relation to N losses. Finally, CoupModel and Daisy were found to be useful simulation tools for analyses of plant evapotranspiration and water balance of complex agroforestry systems. Certain differences occurred between the two models, probably due to model calibration, whereas it is envisaged the average of the results from the two models decrease differences.

\section{Acknowledgements}

The authors are grateful to the organic pig producer Brian Holm and his employees, for making fields and pigs available in order to perform this experiment and for their support throughout the study period. The authors thank Foulumgård experimental station, Kristine Riis Hansen and Orla Nielsen for technical assistance. This study was part of Pig production in ECO-efficient organic SYSTEM project (www.agro. au.dk/forskning/projekter/pecosystem), which is within the Organic RDD 2 Program coordinated by the International Centre for Research in Organic Food Systems (http://icrofs.dk/en/), Aarhus University, and co-funded by the Green Development and Demonstration Program under the Danish Ministry of Food, Farming and Fisheries.

\section{Appendix A. Supplementary data}

Supplementary data associated with this article can be found in the online version, at https://doi.org/10.1016/j.scitotenv.2018.07.376. These data include the Google map of the most important areas described in this article.

\section{References}

Allen, R.G., Pereira, L.S., Raes, D., Smith, M., 1998. Crop Evapotranspiration-Guidelines for Computing Crop Water Requirements-FAO Irrigation and Drainage Paper 56. 300. FAO, Rome, p. 6541

Allerup, P., Madsen, H., Vejen, F., 1997. A comprehensive model for correcting point precipitation Nord Hydrol. 28, 1-20.

Askegaard, M., Olesen, J.E., Kristensen, K., 2005. Nitrate leaching from organic arable crop rotations: effects of location, manure and catch crop. Soil Use Manag. 21, 181-188.

Benjamini, Y., Yekutieli, D., 2001. The control of the false discovery rate in multiple testing under dependency. Ann. Stat. 29, 1165-1188.
Bergeron, M., Lacombe, S., Bradley, R.L., Whalen, J., Cogliastro, A., Jutras, M.-F., Arp, P., 2011. Reduced soil nutrient leaching following the establishment of tree-based intercropping systems in eastern Canada. Agrofor. Syst. 83, 321-330.

Best, E.K., 1975. An automated method for determining nitrate nitrogen in soil extracts. Queensland Department of Primary Industries. Bulletin No. 739. Queensland Wheat Research Institute, Toowoomba, Old 4350, Australia.

Bloemen, J., Fichot, R., Horemans, J.A., Broeckx, L.S., Verlinden, M.S., Zenone, T., Ceulemans, R., 2017. Water use of a multigenotype poplar short-rotation coppice from tree to stand scale. Glob. Change Biol. Bioenergy. 9, 370-384.

Boegh, E., Poulsen, R.N., Butts, M., Abrahamsen, P., Dellwik, E., Hansen, S., Hasager, C.B., Ibrom, A., Loerup, J.K., Pilegaard, K., Soegaard, H., 2009. Remote sensing based evapotranspiration and runoff modeling of agricultural, forest and urban flux sites in Denmark: from field to macro-scale. J. Hydrol. 377, 300-316.

Bonde, M., Sørensen, J.T., 2004. Herd health management in organic pig production using a quality assurance system based on Hazard Analysis and Critical Control Points. NJAS Wagen. J. Life Sci. 52, 133-143.

Bungart, R., Hüttl, R.F., 2004. Growth dynamics and biomass accumulation of 8-year-old hybrid poplar clones in a short-rotation plantation on a clayey-sandy mining substrate with respect to plant nutrition and water budget. Eur. J. For. Res. 123, 105-115.

Confalonieri, R., Orlando, F., Paleari, L., Stella, T., Gilardelli, C., Movedi, E., Pagani, V., Cappelli, G., Vertemara, A., Alberti, L., Alberti, P., Atanassiu, S., Bonaiti, M., Cappelletti, G., Ceruti, M., Confalonieri, A., Corgatelli, G., Corti, P., Dell'Oro, M., Ghidoni, A., Lamarta, A., Maghini, A., Mambretti, M., Manchia, A., Massoni, G., Mutti, P., Pariani, S., Pasini, D., Pesenti, A., Pizzamiglio, G., Ravasio, A., Rea, A., Santorsola, D., Serafini, G., Slavazza, M., Acutis, M., 2016. Uncertainty in crop model predictions: what is the role of users? Environ. Model. Softw. 81, 165-173.

Eriksen, J., 2001. Implications of grazing by sows for nitrate leaching from grassland and the succeeding cereal crop. Grass Forage Sci. 56, 317-322.

Eriksen, J., Kristensen, K., 2001. Nutrient excretion by outdoor pigs: a case study of distribution, utilization and potential for environmental impact. Soil Use Manag. 17, 21-29.

Eriksen, J., Petersen, S.O., Sommer, S.G., 2002. The fate of nitrogen in outdoor pig production. Agronomie 22, 863-867.

Eriksen, J., Hermansen, J.E., Strudsholm, K., Kristensen, K., 2006a. Potential loss of nutrients from different rearing strategies for fattening pigs on pasture. Soil Use Manag. 22, 256-266.

Eriksen, J., Studnitz, M., Strudsholm, K., Kongsted, A.G., Hermansen, J.E., 2006b. Effect of nose ringing and stocking rate of pregnant and lactating outdoor sows on exploratory behaviour, grass cover and nutrient loss potential. Livest. Sci. 104, 91-102.

Fischer, M., Trnka, M., Kučera, J., Deckmyn, G., Orság, M., Sedlák, P., Žalud, Z., Ceulemans, R., 2013. Evapotranspiration of a high-density poplar stand in comparison with a reference grass cover in the Czech-Moravian Highlands. Agric. For. Meteorol. 181, 43-60.

Georgiadis, P., Taeroe, A., Stupak, I., Kepfer-Rojas, S., Zhang, W., Pinheiro Bastos, R., Raulund-Rasmussen, K., 2017. Fertilization effects on biomass production, nutrient leaching and budgets in four stand development stages of short rotation forest poplar. For. Ecol. Manag. 397, 18-26.

Guidi, W., Piccioni, E., Bonari, E., 2008. Evapotranspiration and crop coefficient of poplar and willow short-rotation coppice used as vegetation filter. Bioresour. Technol. 99, 4832-4840.

Gyldenkaerne, S., Albrektsen, R., 2008. Revurdering af ammoniakemissionen 2003-2007. Baggrundsnotat til vandmiljøplan III; Danmarks Miljøundersøgelser. Aarhus Universitet, Tjele, Denmark

Halberg, N., Hermansen, J.E., Kristensen, I.S., Eriksen, J., Tvedegaard, N., Petersen, B.M., 2010. Impact of organic pig production systems on $\mathrm{CO}_{2}$ emission, $\mathrm{C}$ sequestration and nitrate pollution. Agron. Sustain. Dev. 30, 721-731.

Hansen, S., Abrahamsen, P., Petersen, C.T., Styczen, M., 2012. Daisy: model use, calibration and validation. Trans. ASABE 55, 1315-1333.

Hashemi, F., Olesen, J.E., Dalgaard, T., Børgesen, C.D., 2016. Review of scenario analyses to reduce agricultural nitrogen and phosphorus loading to the aquatic environment. Sci. Total Environ. 573, 608-626.

Hermansen, J.E., Jørgensen, U., Lærke, P.E., Manevski, K., Boelt, B., Jensen, S.K., Weisbjerg, M.R., Dalsgaard, T.K., Danielsen, M., Asp, T., Amby-Jensen, M., Aage, C., Sørensen, G., Jensen, M.V., Gylling, M., Lindedam, J., Lübeck, M., Fog, E., 2017. Green Biomass - Protein Production Through Bio-Refining.

Horsted, K., Kongsted, A.G., Jorgensen, U., Sorensen, J., 2012. Combined production of freerange pigs and energy crops-animal behaviour and crop damages. Livest. Sci. 150, 200-208.

IPCC, Intergovernmental Panel on Climate Change, 2006. Guidelines for National Greenhouse Gas Inventories. Available online at. http://www.ipcc-nggip.iges.or.jp/public/ 2006gl/vol4.html (accessed on 18 November 2016).

Jabloun, M., Li, X., Olesen, J.E., Schelde, K., Tao, F., 2014. RDAISY: a comprehensive modelling framework for automated calibration, sensitivity and uncertainty analysis of the DAISY model. Modelling Climate Change Impacts on Crop Production for Food Security (Oslo, Norway).

Jacobsen, O.H., Schjonning, P., 1993. A laboratory calibration of time-domain reflectometry for soil-water measurement including effects of bulk-density and texture. J. Hydrol. 151, 147-157.

Jakobsen, M., Preda, T., Kongsted, A.G., Hermansen, J.E., 2015. Increased foraging in outdoor organic pig production-modeling environmental consequences. Food 4 , 622-644.

Jakobsen, M., Hermansen, J.E., Andersen, H.-M., Jørgensen, U., Labouriau, R., Kongsted, A.G., 2018. Elimination behaviour and soil mineral nitrogen load in an organic system with lactating sows - comparing pasture based systems with and without access to poplar (Populus sp.) trees. Submitted to Agroecology and Sustainable Food Systems. 
Jansson, P.E., Karlberg, L., 2011. Coupled Heat and Mass Transfer Model for Soil-PlantAtmosphere Systems. Royal Institute of Technology, Stockholm, p. 484 (available at:). http://www.coupmodel.com/default.htm.

Jassal, R.S., Black, T.A., Arevalo, C., Jones, H., Bhatti, J.S., Sidders, D., 2013. Carbon sequestration and water use of a young hybrid poplar plantation in north-central Alberta. Biomass Bioenergy 56, 323-333.

Jones, H., Black, T.A., Jassal, R.S., Nesic, Z., Grant, N., Bhatti, J.S., Sidders, D., 2017. Water balance, surface conductance and water use efficiency of two young hybrid-poplar plantations in Canada's aspen parkland. Agric. For. Meteorol. 246, 256-271.

Jorgensen, B., Labouriau, R., LundbyeChristensen, S., 1996. Linear growth curve analysis based on exponential dispersion models. J. R. Stat. Soc. Ser. B Methodol. 58, 573-592.

Jørgensen, U., Thuesen, J., Eriksen, J., Horsted, K., Hermansen, J.E., Kristensen, K., Kongsted, A.G., 2018. Nitrogen distribution as affected by stocking density in a combined production system of energy crops and free-range pigs. Agrofor. Syst. 92 (4), 987-999.

Liberloo, M., Calfapietra, C., Lukac, M., Godbold, D., Luos, Z.B., Polle, A., Hoosbeek, M.R., Kull, O., Marek, M., Raines, C., Rubino, M., Taylor, G., Scarascia-Mugnozza, G., Ceulemans, R., 2006. Woody biomass production during the second rotation of a bio-energy Populus plantation increases in a future high $\mathrm{CO}_{2}$ world. Glob. Chang. Biol. 12, 1094-1106.

Lord, E.I., Shepherd, M.A., 1993. Developments in the use of porous ceramic cups for measuring nitrate leaching. J. Soil Sci. 44, 435-449.

Manevski, K., Børgesen, C.D., Andersen, M.N., Kristensen, I.S., 2015. Reduced nitrogen leaching by intercropping maize with red fescue on sandy soils in North Europe: a combined field and modeling study. Plant Soil 388, 67-85.

Martre, P., Wallach, D., Asseng, S., Ewert, F., Jones, J.W., Rotter, R.P., Boote, K.J., Ruane, A.C., Thorburn, P.J., Cammarano, D., Hatfield, J.L., Rosenzweig, C., Aggarwal, P.K., Angulo, C., Basso, B., Bertuzzi, P., Biernath, C., Brisson, N., Challinor, A.J., Doltra, J., Gayler, S., Goldberg, R., Grant, R.F., Heng, L., Hooker, J., Hunt, L.A., Ingwersen, J., Izaurralde, R.C., Kersebaum, K.C., Muller, C., Kumar, S.N., Nendel, C., O'leary, G., Olesen, J.E. Osborne, T.M., Palosuo, T., Priesack, E., Ripoche, D., Semenov, M.A., Shcherbak, I., Steduto, P., Stockle, C.O., Stratonovitch, P., Streck, T., Supit, I., Tao, F.L., Travasso, M., Waha, K., White, J.W., Wolf, J., 2015. Multimodel ensembles of wheat growth: many models are better than one. Glob. Chang. Biol. 21, 911-925.

Monaghan, R.M., Barraclough, D., 1993. Nitrous-oxide and dinitrogen emissions from urine-affected soil under controlled conditions. Plant Soil 151, 127-138.

Morris, M.D., 1991. Factorial sampling plans for preliminary computational experiments. Technometrics 33, 161-174.

Nemecek, T., Kägi, T., 2007. Life Cycle Inventories of Swiss and European Agricultural Production Systems (Data v2.0. Ecoinvent Report No. 15a. Zurich and Duebendorf).

Nielsen, A.H., Kristensen, I.S., 2005. Nitrogen and phosphorus surpluses on Danish dairy and pig farms in relation to farm characteristics. Livest. Prod. Sci. 96, 97-107.

Olsson, A.-C., Jeppsson, K.-H., Botermans, J., von Wachenfelt, H., Andersson, M., Bergsten, C., Svendsen, J., 2014. Pen hygiene, N, P and K budgets and calculated nitrogen emission for organic growing-finishing pigs in two different housing systems with and without pasture access. Livest. Sci. 165, 138-146.

Petzold, R., Schwärzel, K., Feger, K.-H., 2011. Transpiration of a hybrid poplar plantation in Saxony (Germany) in response to climate and soil conditions. Eur. J. For. Res. 130, 695-706.

Poulsen, H.D., Kristensen, V.F., 1997. Normtal for husdyrgødning. En revurdering af danske normtal for husdyrgødningens indhold af kvælstof, fosfor og kalium. Beretning nr. 736, Danmarks JordbrugsForskning (165 pp (on Danish)).

Pugesgaard, S., Schelde, K., Larsen, S.U., Lærke, P.E., Jørgensen, U., 2015. Comparing annual and perennial crops for bioenergy production - influence on nitrate leaching and energy balance. Glob. Change Biol. Bioenergy. 7, 1136-1149.
Pugesgaard, S., Petersen, S.O., Chirinda, N., Olesen, J.E., 2017. Crop residues as driver for $\mathrm{N}_{2} \mathrm{O}$ emissions from a sandy loam soil. Agric. For. Meteorol. 233, 45-54.

Quintern, M., Sundrum, A., 2006. Ecological risks of outdoor pig fattening in organic farming and strategies for their reduction-results of a field experiment in the centre of Germany. Agric. Ecosyst. Environ. 117, 238-250.

R Core Team, 2013. R: A Language and Environment for Statistical Computing. R foundation for statistical computing, Vienna (Austria).

Stauffer, W., Menzi, H., Trachsel, P., 1999. Gefährden freilandschweine das grundwasser? Agrarforschung 6, 257-260.

Taeroe, A., Nord-Larsen, T., Stupak, I., Raulund-Rasmussen, K., 2015. Allometric biomass, biomass expansion factor and wood density models for the OP42 hybrid poplar in southern Scandinavia. Bioenergy Res. 8, 1332-1343.

Thevathasan, N.V., Gordon, A.M., Bradley, R., Cogliastro, A., Folkard, P., Grant, R., Kort, J. Liggins, L., Njenga, F., Olivier, A., Pharo, C., Powell, G., Rivest, D., Schiks, T., Trotter D., Van Rees, K., Whalen, J., Zabek, L., 2012. Agroforestry research and development in Canada: the way forward. In: Nair, P.K.R., Garrity, D. (Eds.), Agroforestry - The Future of Global Land Use. Springer Netherlands, Dordrecht, pp. 247-283.

Thorslund, C.A.H., Aaslyng, M.D., Lassen, J., 2017. Perceived importance and responsibility for market-driven pig welfare: literature review. Meat Sci. 125, 37-45.

Vinther, F.P., Hansen, S., 2004. SimDen - A Simple Tool for Estimating Denitrification and $\mathrm{N}_{2} \mathrm{O}$ Emission in Agricultural Soils (DJF rapport, Markbrug nr. 104 (on Danish))

Webb, J., Broomfield, M., Jones, S., Donovan, B., 2014. Ammonia and odour emissions from UK pig farms and nitrogen leaching from outdoor pig production. A review. Sci. Total Environ. 470, 865-875.

Williams, J.R., Chambers, B.J., Hartley, A.R., Ellis, S., Guise, H.J., 2000. Nitrogen losses from outdoor pig farming systems. Soil Use Manag. 16, 237-243.

Williams, J.R., Chambers, B.J., Hartley, A.R., Chalmers, A.G., 2005. Nitrate leaching and residual soil nitrogen supply following outdoor pig farming. Soil Use Manag. 21 245-252.

Worthington, T.R., Danks, P.W., 1992. Nitrate leaching and intensive outdoor pig production. Soil Use Manag. 8, 56-59.

Yin, X., Kersebaum, K.C., Kollas, C., Baby, S., Beaudoin, N., Manevski, K., Palosuo, T., Nendel, C., Wu, L., Hoffmann, M., Hoffmann, H., Sharif, B., Armas-Herrera, C.M., Bindi, M., Charfeddine, M., Conradt, T., Constantin, J., Ewert, F., Ferrise, R., Gaiser, T., de Cortazar-Atauri, I.G., Giglio, L., Hlavinka, P., Lana, M., Launay, M., Louarn, G., Manderscheid, R., Mary, B., Mirschel, W., Moriondo, M., Öztürk, I., Pacholski, A., Ripoche-Wachter, D., Rötter, R.P., Ruget, F., Trnka, M., Ventrella, D., Weigel, H.-J., Olesen, J.E., 2017a. Multi-model uncertainty analysis in predicting grain $\mathrm{N}$ for crop rotations in Europe. Eur. J. Agron. 84, 152-165.

Yin, X., Kersebaum, K.C., Kollas, C., Manevski, K., Baby, S., Beaudoin, N., Öztürk, I., Gaiser, T. Wu, L., Hoffmann, M., Charfeddine, M., Conradt, T., Constantin, J., Ewert, F., de Cortazar-Atauri, I.G., Giglio, L., Hlavinka, P., Hoffmann, H., Launay, M., Louarn, G., Manderscheid, R., Mary, B., Mirschel, W., Nendel, C., Pacholski, A., Palosuo, T., Ripoche-Wachter, D.P., Rötter, R., Ruget, F., Sharif, B., Trnka, M., Ventrella, D., Weigel, H.-J., Olesen, J.E., 2017b. Performance of process-based models for simulation of grain $\mathrm{N}$ in crop rotations across Europe. Agric. Syst. 154, 63-77.

Zenone, T., Fischer, M., Arriga, N., Broeckx, L.S., Verlinden, M.S., Vanbeveren, S., Zona, D. Ceulemans, R., 2015. Biophysical drivers of the carbon dioxide, water vapor, and energy exchanges of a short-rotation poplar coppice. Agric. For. Meteorol. 209, 22-35. 